К.С.Шевчук,

кандидат філософських наук, дочент кафедри філософії РДГУ

\title{
ЕСТЕТИКА ЕЛЕКТРОННИХ МЕДІА: АНАЛІЗ ОСНОВНИХ ПРОБЛЕМ
}

Стрімкий розвиток нових технологій, що з другої половини $\mathrm{XX}$ ст. викликав зміни у різних сферах життя людини, не оминув гуманітарної царини. Зміни стосуються також естетики, яка, будучи теорією мистецтва, покликана відповідати на запити сучасної сфери образотворення, яка теж зазнала кардинальних трансформацій. Останніми десятиліттями спостерігаємо, зокрема, появу нових напрямків і течій як у сучасному мистецтві, так і в естетичній теоpiï. Серед них чільне місце займає естетика нових медіа. Про актуальність естетики нових медіа, або електронних медіа, свідчать дослідження даної проблематики багатьма відомими теоретиками (Ж.-Ф.Ліотар, П.Вірільо, В.Вельш).

Проблеми естетики медіа виростають на межі традиційної естетики та теорії медіа і пов'язані з необхідністю реінтерпретації таких понять, як творчість, медіа, техніка, сприйняття, а також із запровадженням нових понять - віртуальність, інтерактивність, імерсійність тощо. Тому сьогодні важливою є співпраця теоретиків мультимедіа і представників філософської естетики $[10,287]$.

У царині мультимедійної естетики можна виокремити декілька проблемних блоків. Один із них пов'язаний з визначенням поняття «мистецтво», зважаючи на те, що медіа є місцем народження творчості «нового типу». Зазвичай естетики використовують деякі поняття традиційної естетики як філософії мистецтва, особливо ті, що стосуються естетичної ситуації, хоча й усвідомлюють необхідність їх модифікації. Наприклад, якщо йдеться про автора, то в контексті естетики медіа підкреслюється суттєва відмінність творчого процесу, в якому беруть участь машина зі штучним інтелектом і традиційне образотворення. Тому процес появи твору електронного мистецтва найчастіше називають генеруванням, а не творенням. Увага звертається також на зміни у сфері уяви, сутності самого твору, а також у процесі його сприйняття. 
Суттєвим є питання буттєвого тла твору, яке часто називають імматеріальним, адже мультимедійний твір перебуває у сфері віртуальної реальності.

Твори електронного мистецтва (графіка, сателітне мистецтво, Інтернет-мистецтво), як і відео-скульптури, запрошують реципієнта вийти на контакт, що відсилає нас до проблеми сприйняття. Якщо процес сприйняття творів традиційного мистецтва найчастіше окреслюють за допомогою поняття «естетичне переживання», то сприйняття творів електронного мистецтва називають «інтерактивність». Інтерактивність - це новий спосіб контактування з образами, що $\epsilon$, по суті, двосторонньою комунікацією між людиною і машиною. Це означає, що образи такого типу, які не лише змушують глядача до реакції, а й самі реагують на поведінку реципієнта, є можливими лише в царині high tech.

Ж.-Ф.Ліотар, а також В.Вельш звертають увагу на те, що електронні медіа, які оперують швидкістю світла і пропонують образ нової генерації, змушують змінюватися весь апарат сприйняття людини. При цьому важко передбачити силу, розмір і наслідки цих змін. Під впливом медіа сприймаємо більше й інакше. На глобальність цих змін звертає увагу дослідниця мультимедійного мистецтва А.М.Боннет. Вона твердить, що змінюються не лише образи, а й сам характер спостереження.

Зміни стосуються самого порядку сприйняття, що, з одного боку, узгоджується 3 лінеарністю раціонального мислення, а $з$ іншого веде до того, що образи з медіа втрачають міметичність. Однак образи, що виринають у середовищі електронної абстракції, постають внаслідок не абстрактної думки, а апарату чуттів, який має відповідати новій ситуації. Коли у 1985 р. Ж.-Ф.Ліотар організовував мультимедійну виставу, то зважав на складність цієї ситуації і ставив перед митцями завдання формування нової чуттєвості або закликав підготувати широкі маси суспільства до спілкування зі всім тим, що несуть нові технології.

Нові технології буквально закидають нас образами, тому естетика, вразлива до змін, породжених медіа, повинна встояти перед викликом нової проблематики під рубрикою «інвазія (вторгнення) образів». Новизна цієї проблематики полягає в тому, що ці образи вже не є міметичними, а тому система їх відношень, а також принципи суспільного функціонування потребують серйозного вивчення. 
Важливими сьогодні є дослідження, спрямовані на визначення статусу електронного мистецтва, можливості втілення в ньому естетичних цінностей як таких і також виявлення їх можливої модифікації.

Як відомо, впродовж історії однією 3 головних естетичних цінностей вважалося прекрасне. Дослідники медіа мистецтва сьогодні говорять про явище трансгресії прекрасного. У час, коли відбувається екстраполяція естетичних цінностей на позаестетичну площину, актуальними є дослідження різних способів функціонування прекрасного, його проявів і втілення, особливо, якщо йдеться про прекрасне, яке використовується в електронних медіа. Цьому сприяють хоча б такі властивості прекрасного, як викликання задоволення і бажання, що пов'язане 3 позитивним емоційним переживанням, здатність до трансгресії чи рецептивність, що є виразом прекрасного і веде до того, що прекрасне може «втілитися».

Медіа-перекази насичені ідеалізованими постатями, гарними предметами і красою людського тіла, що ідентифікується 3 тим, що є благом. Результати досліджень соціальної психології свідчать про асоціативний зв'язок прекрасного з етичними якостями, якими ми схильні наділяти гарних людей. Крізь призму фізичної привабливості певної людини, позитивної якості набувають також інші їі риси. Тому фізична краса є сталим елементом медіа-переказу і має відношення як до вигляду, так і до ходи осіб, їхньої жестикуляції або ж тембру голосу.

Ще одним видом трансгресії прекрасного є ефект асоціації, викликаний ефектом сусідства, коли речі, які перебувають в оточенні того, що - прекрасне, сприймаються як те, що є найціннішим. Такий тип трансгресії активно використовується, зокрема, в рекламі. Розташування предмета реклами поряд 3 привабливими речами надає ваги товару, а також створює переконання, що для того, щоб стати привабливим, достатньо придбати цей товар. Натомість «відкриття» прекрасного в предметі щоденного вжитку веде до зміни статусу прекрасного і його цінності, оскілки схоплення прекрасного як речі, яку можна купити, нівелює тим самим його незвичайність i сприяє його поширенню.

Ще одним аспектом проблеми, пов'язаної з навіюванням прекрасного в медіа, $є$ можливості, що відкриваються сьогодні у зв'язку 3 використанням техніки, яка робить можливою ще більшу ідеалізацію предмета. Сучасна комп’ютерна графіка, нові методи виконання 
великоформатних фото сприяють естетизації або навіть надестетизації нашої повсякденності. 3 цим пов'язана небезпека того, що створені шляхом технологічної естетизації повідомлення, насичені багатьма елементами, щоб сподобатися реципієнтам, часто підпадають під владу стереотипу і кічу.

Сприйняття прекрасного, викликаного навіюванням, що використовується в медіа, відрізняється від сприйняття прекрасного в художньому творі. Зв'язок прекрасного з цінностями ужитку робить прекрасне предметом споживання і вираженням повсякденності, внаслідок чого нівелює його визначальну рису, а саме - бути цінністю самою в собі, позбавляє його характерного ареолу таємничості. Як зауважує Сва Щенсна, прекрасне, яке стане доступним кожному, хто піддасться навіюванню, насправді не виходить за межі обітниці і гри в навіювання $[8,277]$.

Розвиток цифрових медіа-технологій сприяє нівеляції відмінності між способами сприйняття різних форм функціонування прекрасного. Раніше вважалося, що естетичне переживання природи відрізняється від сприйняття мистецтва, адже в естетичному пізнанні природи беруть участь всі відчуття, тоді як різні види мистецтва сприймаються різними органами чуттів: образотворче мистецтво - зоровими, музика - слуховими, кіно - зоровими і слуховими та ін. 3 появою цифрових технологій, що творять віртуальний світ, де відбувається зняття будь-яких обмежень, симулюється участь багатьох відчуттів.

У зв'язку з розвитком Інтернет-мистецтва зростає увага до виду відчуття, якому раніше приділяли чи не найменше уваги в естетичних дослідженнях. Йдеться про відчуття дотику. Дотик є одним із тих відчуттів, за допомогою якого ми спілкуємося зі світом. Як зауважував Е.Б.деКондільяк, лише дотик дає можливість людині усвідомити свою тілесність, сприйняти себе як окремий вид буття. Крім того, дотик впливає на інші відчуття, вдосконалює їх.

У сучасних дослідженнях 3 естетики підкреслюється зв'язок дотику 3 інтимною сферою людини, його безпосередність тощо, оскільки до дійсності, представленої за його допомогою, можна доторкнутися. Особливою рисою дотику є те, що «відчуття дотику єдине забезпечує повне ангажування, адже торкатися означає одночасно бути доторкнутим, така «зворотність» не властива жодному іншому відчуттю» $[9,183]$. Це єдине відчуття, що одночасно діє і 
сприймає. Дотик, таким чином, є двостороннім явищем. «Це світ торкається нас, коли ми торкаємося його» $[1,59]$.

Сучасне Інтернет-мистецтво дає змогу по-новому подивитися на значення дотику у нашому сприйнятті світу, адже цей вид мистецтва підкреслює важливість нашого існування, оскільки без залучення реципієнта не може виникнути твір мистецтва. При цьому зростає роль реального контакту. Якщо раніше вистачало лише уважно вдивлятися в художню реалізацію і мислити, то стосовно інтерактивних творів слід спочатку ініціювати акцію, проголошуючи свою участь у ній. Вибір, який ми робимо, натискаючи клавіші, дає нам відчуття індивідуального вибору, такого важливого в сучасному постіндустріальному світі. «Кожен користувач інтерактивної інсталяції отримує власну версію твору. Таким чином, технологія нових медіа функціонує як досконало реалізована утопія ідеального суспільства, яке складається 3 неповторних особистостей» [5, 109]. Індивідуалізований вибір пов'язаний 3 відповідальністю. Акт участі реципієнта - це, водночас, згода на часткову відповідальність за твір.

Дотик не пов'язаний $з$ якимось одним органом у тілі людини, як у випадку інших відчуттів. Його специфікою $є$ те, що задіяним $є$ все тіло, оскільки не лише долоні можуть торкатися; дотик тіла більше інтригує, ніж потиск долонь. Таким чином, можна говорити про тіло як про специфічний інтерфейс. Як зауважує Б. Лаурель, «інтерфейс це специфічна поверхня контакту, це баланс сили і контролю, що визначає пізнавальні і емоційні аспекти досвіду користувача».

Торкаючись, ми вступаємо у зв'язок. Виникає питання: з чим вступаємо в контакт - 3 машиною, думкою, концепцією творця чи створеною віртуальною реальністю? Лев Мановіч стверджує, що інтерактивні медіа схиляють нас до ідентифікації з чиєюсь ментальною структурою. «Кіноглядач прагне наслідувати зірок фільму, натомість користувач комп'ютера схиляється до прямування ментальною дорогою творця нових медіа» $[5,135]$. Іншої думки дотримується М.Круегер. Він стверджує, що твір мистецтва є інтеракцією між людиною і машиною, в якій митець відіграє роль медіатора.

Наше тіло, яке, без сумніву, відіграє ключову роль у процесі інтерактивного сприйняття, в контексті мультимедійного мистецтва $\epsilon$, однак, неоднозначним. Виникає питання: де закінчується наше тіло, яке піддається дотикові? Юстина Ричек стверджує, що наше тіло, як замкнена брила, починає втрачати свою окремішність і свої межі. 
Численні протези проникають у нього і стають його частинами $[6,605]$.

У зв'язку з глибокими технологічними змінами виникає питання: чи тіло може мати лише фізичний вимір? Дотик прояснює нам наш зв'язок зі світом, безперервний контакт і співіснування. Не можемо позбутися дотику і відкинути контакт. Це дає можливість твердити, що ми є буттям, не зовсім відокремленим від інших, ніби відділені, але налаштовані на постійний пошук контакту.

Дотик збагачує новими навичками, підвищує чутливість до дійсності. Розширення можливостей відкриває людині іï зв’язок 3 іншими, доносить до неї, що вона є відповідальною за свої рішення, що впливають на «стан здоров'я землі». Людина стає особою причетною $[3,95]$.

Досить цікавими є роздуми про конструювання зв'язків між різними видами медіа в контексті Інтернету, який багатьма вважається новим явищем, що потребує комплексного дослідження. Деякі дослідники, наприклад Конрад Хмелецьки, вважають, що Інтернет ще не виконує роль і певного медіуму, а є лише платформою для функціонування вже існуючих засобів передачі інформації. Дослідник визнає, що Інтернет може бути сприятливим середовищем для встановлення зв'язків між медіа, і допускає, що в майбутньому Iнтернет буде розвиватися також іншим шляхом [2, 535]. Натомість, на думку М.Санбота, Інтернет є досить складним і вразливим трансмедіумом, в якому різні аспекти, підпорядковані раніше окремим медіа-світам, завдяки різноманітним інноваціям переплелися таким чином, що створюють враження якогось нового медіуму [7, 205].

Аргументом на користь включення міркувань про Інтернет в дослідження інтермедійної естетики $є$ те, що Інтернет може реалізуватися в межах медіа-зв'язків між вже існуючими медіа.

За прогнозом Жана Янгблуда, незабаром має з'явитися глобальна «сітка інтермедіа», яка братиме активну участь у конструюванні суспільної комунікації. Але вже сьогодні значно зросла роль Інтернету не лише як засобу спілкування і передачі інформації, а й як певного інструмента впливу на формування суспільної свідомості. Розвиток Інтернету має вплив також на сучасну художню практику. Р.Клющинський щодо цього зауважив: «Сучасне мистецтво вже не міститься в межах окремих дисциплін, не дає можливості аналітично себе осягнути, а тим більше підпорядкувати за допомогою традиційних категорій пізнання. Епоха мережевого суспільства, змінних 
i безперервно реконструйованих ідентичностей, епоха, в якій комунікація стає головною формою суспільної активності, фундаментом і основою функціонування інституцій, що організовують ці практики, не сприяють художній чистоті видів мистецтва та пошуку специфічних рис. Творчість сьогодення, принаймні та, що веде діалог з сучасністю, - це поліфонічне, зі значним потенціалом, багатовимірне мультимедійне, інтермедійне, гіпермедійне мистецтво, що доводить до краю ініційований колись романтизмом процес кореспонденції мистецтв» $[4,9]$. Можна сказати, що змальоване у такий спосіб предметне поле інтермедійної естетики відкриває простір для теоретичного дослідження сучасного медіа-мистецтва.

Зміни, які відбуваються в нашому житті під впливом медіа, сприяють зростанню уваги до цієї проблеми. У світі з'явилося декілька центрів мультимедійного мистецтва і технологій: найбільші розташовані в Німеччині, США і Японії, а мислителі такого рівня, як Жан Бодрійяр, Поль Вірільо, Вілем Флуссер, Норберт Больц та ін., намагаються теоретично (в естетичному аспекті, зокрема) дослідити проблему домінування в сучасній культурі електронних медіа. Помітно зростає кількість вистав, присвячених презентації мистецтва електронних медіа. При цьому все ж важко говорити про естетику нових медіа, адже на сьогодні існують лише ії фрагменти, розпорошені у працях теоретиків нових медіа, філософів культури, а також естетиків. Можна, однак, сподіватися, що незабаром ці фрагменти складуться в одну, але різну за проблематикою, естетику електронних медіа.

\section{ЛІТЕРАТУРА}

1. Brach-Czaina J. Błony umysłu. - Warszawa, 2003. - $113 \mathrm{~s}$.

2. Chmielecki K. Od poezji wizualnej do kina interaktywnego // Wizje i rewizje. Wielka księga estetyki w Polsce. - Kraków, 2007. - C.523-537.

3. De Kerckhove D. Powłoka kultury: odkrywanie nowej elektronicznej rzeczywistości. - Warszawa, 2001. - 219 s.

4. Kluszczyński R.W. Słowo wstępne // (Nie)obecne granice. - Kraków, 2003. - C.9.

5. Manovich L. Język nowych mediów. - Warszawa, 2006. - $484 \mathrm{~s}$.

6. Ryczek J. Dotykaj! Odbiorca wobec sztuki mediów. Rozważania teoretyczne // Wizje I re-wizje. Wielka księga estetyki w Polsce. - Kraków, 2007. - C.601-609.

7. Sandbothe $M$. Transwersalne światy medialne. Filozoficzne rozważania o Internecie // Widzieć, myśleć, być. Technologie mediów. - Kraków, 2001.-C.205-222.

8. Szczęsna E. Perswazyjność piękna // Wizje I re-wizje. Wielka księga estetyki 
w Polsce. - Kraków, 2007. - C. 265-276.

9. Wilkoszewska K. Estetyka dotyku // Słowo w kulturze mediów. - Białystok, 1999. - C. 183-187.

10. Wilkoszewska $K$. Nowe media. Nowe inspiracje w estetyce drugiej połowy XX wieku // Estetyki filozoficzne XX wieku. - Kraków, 2000. - C.287-291.

Шевчук К.С. Естетика електронних медіа: аналіз основних проблем.

У статі здійснюється аналіз основних проблем естетики електронних медіа, пов'язаної з розвитком мультимедійного мистецтва. Основну увагу автор звертає, зокрема, на такі моменти, як: статус медіа-мистецтва, реінтерпретація понять традиційного мистецтва, трансформація естетичних цінностей, роль відчуттів у сприйнятті Інтернет-мистецтва тощо. Розглядаються також подальші перспективи розвитку естетики електронних медіа.

Ключові слова: естетика, медіа, інтерактивність, прекрасне, трансгресія, сприйняття, відчуття, дотик, електронне мистецтво, твори мультимедіа, Інтернет-мистецтво.

Шевчук Е.С. Эстетика электронных медиа: анализ основных проблем.

В статье проведен анализ основных проблем эстетики электронных медиа, которая связана с развитием мультимедийного искусства. Основное внимание автор обращает, в частности, на такие моменты, как: статус медиа-искусства, реинтерпретация понятий традиционного искусства, трансформация эстетических ценностей, роль ощущений в восприятии Интернет-искусства и др. Рассматриваются также дальнейшие перспективы развития эстетики электронных медиа.

Ключевые слова: эстетика медиа, интерактивность, прекрасное, трансгрессия, восприятие, ощущение, прикосновение, электронное искусство, произведения мультимедиа, Интернет-искусство.

Shevchuk K. Aesthetics of electronic media: the analysis of main problems.

The article is devoted to the main problems of aesthetics of electronic media that is connected to the development of multimedia art. Author pays attention to the status of media art, re-interpretation of traditional art's concepts, transformation of aesthetical values, the role of feelings in perception of Internet art etc. In the field of multimedia aesthetics it can be identified several problematic blocks. One of them is the definition of art, despite the fact that the media is the birthplace of «new type» creativity. The important problem is connected to the ontological background of art, which is often called immaterial. The further perspectives of aesthetics of electronic media are also investigated in the present article.

Key words: aesthetics, media, interactivity, beauty, transgression, perception, feeling, electronic art, media art, Internet art. 